\title{
Potential Benefits of Monitoring and Evaluation as a Tool in the South African Local Government Spheres
}

MLE, T. R

\section{Abstract}

$\mathrm{P}$ ublic institutions exist for the public good and employ public officials to perform duties aimed at providing a better life for all. The Constitution of the Republic of South Africa, 1996 requires that the public service maintains a high standard of professional ethics, use resources efficiently and effectively, and provide services equitably.

When the new political dispensation came into being in 1994 in South Africa, the newly-elected government committed itself to ensuring a better life for all through the provision of services, for example water and electricity supply, sanitation, and houses, etc. To this end, policies and programmes were put in place. However, the challenge that faces the government is the implementation of these policies and programmes which largely remains unsatisfactory. Systems of reporting and performance are, in the main, weak. To address this short-coming, therefore, government came up with the concept of monitoring and evaluation of the implementation of policies and programmes to the extent of creating a new department of Performance Monitoring and Evaluation in the Presidency.

Key to the effective implementation of government policies and programmes is the introduction of a tool to ensure that such policies and programmes do not gather dust. This paper therefore, posits how such a tool can have potential benefits in the local government sphere and be a panacea to the ills of this sphere which is characterized by violent service delivery protests through which communities express their dissatisfaction at the non-delivery of essential services.

Keywords: Monitoring and Evaluation, Ethics, South Africa. Public Institutions, Performance, Service Efficiency, Policies and Programmes 
Africa's Public Service Delivery \& Performance Review 57

\section{Introduction and Background}

The welfare of people living in a community is the principal, overall objective of any government. Every government, therefore, must endeavour to promote the general welfare of its citizens (De Bruijn and Dick, 2006:79). One of the processes of public administration is human resource and thus for services to be rendered by a department or municipality there is a need for personnel to be employed and attached to specific posts within the organizational structure of the particular department or municipality. This process is accompanied by, inter alia, allocation of functions, delegation of authority, creation of communication channels and behavioural relationship.

Such personnel employed, sometimes referred to as functionaries, are charged with the task of ensuring that departments or municipalities' goals are achieved through efficient and, effective performance of duties, the requisite for success being ethical conduct, trust and professionalism on the part of the functionaries (Shafritz and Russel, 2005:15). A government would also formulate policies which can be defined as statement of ideals proposed or adopted.

In a sense, the purpose of policy is to reveal the intentions of government to attain specific goals. (Fox, Schwella and Wissink 1991:28) say "policy is what governments actually do..." A government would as well have programmes which can be seen as a plan of what is (intended) to be done.

Policies and programmes are compatible and their proper implementation is what determines the failure or success of a government. This implementation is, however, in the hands of the employed public functionaries who sometimes do not live up to expectation, thereby necessitating the employment of interventions in the form of monitoring and evaluation tools.

The focus of this paper is on the local sphere of government and this is so because this sphere is by its very location of being nearer to communities, in the South African context, seen as the delivery arm of government in ensuring the provision of basic services for example water, electricity, sanitation, etc, to the citizens. In terms of the Constitution 1996, it has "the right to govern, on its own initiative, the local government affairs of its communities" (Clause 151(3). Furthermore, it is obliged by the Constitution to, "provide democratic and accountable government for local communities; and ensure 
the provision of services to communities in a sustainable manner" (clause 152(1), but it fails to rise to the occasion and comply with the Constitutional obligation of an accountable system of governance. There is poor implementation of policies and programmes, and evidence of this contention are the daily violent service delivery protests by communities in which citizens express their dissatisfaction with the manner in which this sphere of government conducts its core business, basically non-delivery of expected services. Adverse audit opinions on Municipalities are also testimony of the absence of good governance, professionalism, ethics and integrity (Kondlo \& Maserumule 2010:77). This state of affairs can thus not be left unattended and has to be addressed, hence the importance of monitoring and evaluation.

What monitoring and evaluation measures can then be put in place to turn the situation around and ensure better implementation of policies and programmes? To answer this question, this article looked at legislation relevant to local government and pertinent literature.

\section{Monitoring and evaluation measures aimed at better implementation of government policies, programmes and productivity}

Ijeoma, Nzewi and Sibanda (2013: 320) define monitoring as, "the consistent and systematic collection of information and data during a project implementation or progress with the aim of improving the efficiency and effectiveness of the project...." The authors see evaluation as "any effort to increase human effectiveness..." In this context therefore, the following measures are suggested:

\section{The Local Government Municipal systems amendment act, 2011}

An area of concern in municipalities is the appointment of personnel without the appropriate qualifications. This negates the whole question of ensuring human effectiveness. To remedy the situation therefore, government enacted the Local Government Municipal Systems Amendment Act, 2011. The Act seeks to ensure that candidates appointed to senior municipal management positions are suitably qualified; this in essence may enhance productivity and increase efficiency and effectivity.

Furthermore, the Act proposes that municipal officials found guilty of fraud and corruption may not be employed in any municipality for at least 10 years. This can be 
seen as a panacea to obviate unethical conduct in municipalities and thus ensure clean governance. The Act, which can be seen as a monitoring and evaluation tool, further promotes the effective monitoring of inter-departmental transfers and promotions to guard against public institutions operating in silos. This silo syndrome caught the eye of the Public Service Commission which noted that officials who are involved in criminal acts, resign before action is taken against them and accept appointment in another department or municipality without being noticed (Public Service Commission Report 2010:11).

\section{The Local Government Municipal Systems Amendment Act, 2000 (32 of 2000)}

The Local Government Municipal Systems Act 2000 provides for the core principles, mechanisms and processes that are necessary to enable municipalities to move progressively towards the social and economic upliftment of local communities and to ensure universal access to essential services that are affordable to all. It also provides for the manner in which municipal powers and functions are exercised and performed. It further provides for the building of local government into an efficient development agency for the overall social and economic upliftment of communities. To achieve these objectives, the Act sets out a Code of Conduct for Councillors and Municipal staff members.

The Act obliges elected Councillors to put in place mechanisms of answerability to local communities, and to meet the priority needs of communities by providing services equitably, effectively and sustainably within the means of the municipality. It further enforces on Councillors accountability to communities and to report back at least quarterly to constituencies on council matters including the performance of the municipality in terms of the established key performance areas. Furthermore, in terms of the Act, the following are expected of Councillors:

- Performance of functions of office in good faith, honestly, and in a transparent manner. 
- Act in the best interest of the municipality so as not to compromise its credibility and integrity.

- Disclose to the municipal council any direct or indirect personal or private business interest that a councillor or any spouse, partner or business associate of that councillor may have in any matter before the council.

- Not use the position or privileges of being a councillor or confidential information obtained as a councillor for private gain or to improperly benefit another person.

- Not except with the prior consent of the Municipal Council, be a party to or beneficiary under a contract for the provision of goods and services to the municipality.

- Not request solicit or accept any reward gift or favour for disclosing privileged or confidential information.

The contents of the Code of Conduct for Councillors apply mutatis mutandis to Municipal staff members (Local Government Municipal Systems Act, 2000 Schedule 1 and 2). The Local Government Municipal Structures Act, 1998 (117 of 1998) also sets out the Code of Conduct for Councillors (Schedule 5) as contained in the Local Government Municipal Systems Act, 2000 (Schedule 1).

To further promote and encourage an efficient, effective system of good governance at the local sphere, the Handbook for Municipal Councillors was developed.

The Handbook (Chapter 3) sets out the roles and responsibilities of Councillors; the objective being to equip them with the knowledge and skills that will enable them to carry their work and understand their role. Good governance is described in the Handbook as where the highest quality services are delivered at the lowest cost possible for the benefit of all stakeholders. The Handbook clearly states that councillors need to be aware of the financial implications of decisions they make, as good financial management by council is important for the promotion of good governance. It is for this reason that the Handbook provides an introduction to financial management and budgeting processes, and clarifies the role of Councillors in relation to these. In this regard the Municipal Finance Management Act 2003 requires Councillors, as elected officials, to play an active part in financial management. If strictly adhered to, the local 
Africa's Public Service Delivery \& Performance Review 61

Government Municipal Systems Act, Code of Conduct for Councillors and the Handbook for Municipal Councillors can be useful monitoring and evaluation tools.

\section{Citizens as monitoring and evaluation tools}

The Constitution of the Republic of South Africa, 1996 (Clause 152(1)(e) states, "The objects of local government are to encourage the involvement of communities and community organizations in the matters of local government."

The Handbook for Municipal Councillors 2003 (Chapter 13) endorses this Constitutional obligation and explores the role of Community Development Workers and Ward Committees.

Ward Committees are a link between the community and the municipality and are meant to make a municipality answer for its actions/inactions. According to the Public Service Commission this is, however, not the case because councillors do not attend ward committee meetings (Public Service Commission Report 2010:41) and therefore, ward committee issues are not tabled in council meetings. It can be stated that if properly utilized, community based structures can be effective monitoring and evaluation tools that may ensure good governance. Citizen participation in the activities and programmes of a municipality is a recipe for good governance. This assertion is underscored by Ijeoma et al., (2013:206) quoting Epstein (2006) thus, "...getting citizens involved in getting things done is a good governance practice which encourages community problem solving, in essence it means a community having ownership or what can be termed "voice" in the process of solving their own problems...citizens or community members have a voice in the monitoring and evaluation of the results ..." Citizen participation in the affairs of a municipality promotes a sense of pride and belonging on the part of citizens and this is missing; what prevails is the "us" (Communities) and "them" (Municipality) syndrome. Put succinctly, there is a gap between the citizens and municipalities. According to Dumisani Mpafa (Daily Dispatch 15 October 2013:9) of the Black Management Forum Eastern Cape, "Countries that epitomize fully capable statehood and that have achieved the best ratings in terms of clean governance have a tradition of government openness, civic activism and social trust, and strong accountability mechanism that allows citizens to monitor their 
municipal officials and councillors and hold them accountable." Building a tradition of government openness is about instilling a doctrine in municipal officials and councillors that citizens and ratepayers are the shareholders of South Africa Incorporated and has the right to access the documents and proceedings of local government, to allow for effective public oversight. This key tenet of democracy must not be taken lightly. Citizens and ratepayers are entitled to know what their municipalities are doing, how decisions are made, and to make their voices heard. Government openness is about pro-active and timely government disclosure of useful public information that will empower citizen action and help individuals and organizations to effect positive change in their communities.

Craythorne (2003:204), however, warns that public participation must not be allowed to degenerate into interference with a municipal council's right to govern, that in essence means that a balance must be struck between citizen participation and the legal authority of a municipality to govern.

\section{The National Anti-corruption Hotline (NACH)}

The National Anti-corruption Hotline (N.A.C.H) was established in 2003 (Cabinet Memorandum 45 of 2003) as a tool to monitor corrupt tendencies and practices in public institutions. This tool has, however, not been effective as intended, because of bureaucracy and red tape. Thakhathi (Inaugural address, 2013) makes the point that the public service must be transformed from bureaucracy to revocracy. It is too rule-bound. Regarding the N.AC.H for example, corruption cases at the local sphere are reported to the P.S.C nationally and are processed via the provincial sphere to the local sphere for investigation. To be effective as a monitoring and evaluation tool, cases need to be reported directly at the sphere where they happen and be investigated immediately. Coupled with this contention is the need to capacitate officials to enable them to handle such cases.

The N.A.C.H. is closely linked to whistle-blowing - a monitoring and evaluation tool that has not yielded the expected results; the reason being that whistle blowers are not afforded the necessary protection. If properly managed and implemented, whistle blowing can be an effective monitoring and evaluation tool to ensure appropriate implementation of government policies and programmes. 
Africa's Public Service Delivery \& Performance Review 63

\section{Monitoring and Evaluation Commission}

Chapter 9 of the Constitution, 1996 establishes state institutions that promote constitutional democracy which are appointed by Parliament. They are independent and are responsible to and answer only to Parliament. Monitoring and evaluation and better implementation of government policies and programmes may require the establishment of an additional Chapter 9 institution in the form of a Monitoring and Evaluation Commission.

Article 6 (1) of the U.N Convention requires each state to establish a body to obviate corruption (United Nations Corruption Convention: 2005) and the Monitoring and Evaluation Commission could be set up along the same principle. The commission would complement the task of the Ministry of Performance Monitoring and Evaluation in the Presidency (Ijeoma et al., 2013: 317) just as, for example, Provincial Auditor-General Offices, Treasury Offices and other provincial institutions complement or enhance the functions of national departments. The Monitoring and Evaluation Commission would need to establish Provincial Commissions as is the case with the Public Service Commission. The main task of the Commission would be to monitor, research, educate, advise and report on issues concerning the implementation of government policies and programmes. Performance agreements shall need to be signed with policy and programmes implementers. Such agreements will, inter-alia, indicate deliverables and time-frames for which the implementers shall be held answerable.

\section{Political leadership}

Political leadership is critical in ensuring the effective implementation of government policies and programmes. The Auditor-General (2010/11 report) cited lack of political leadership as one of the reasons for poor management in municipalities. Political leaders need to take ownership of government policies and programmes and play a major role in monitoring their implementation. A state requires leadership, sound policies, skilled managers and workers, clear lines of accountability, appropriate systems and consistent and fair application of rules. 


\section{Potential Benefits of Monitoring \& Evaluation in the South African Local Govt Spheres}

What characterizes municipalities is political instability, infighting and jostling for power and positions. Administrators, as policy and programme implementers, take advantage of such situations and simply lax in performing their duties.

\section{Induction and training programmes}

When a candidate is employed in the public service, he/she is inducted into the job situation through an induction programme which introduces the candidate to the work environment including rules and regulations. The candidate will be introduced to his/her supervisor, peers/workmates and be orientated on the vision and mission of the department. The candidate shall then be provided with a work plan which has the job content and how to go about carrying out the functions assigned to the post the candidate occupies (Public Service Regulations, 2001:14). The programme can be said to be superficial and may need to be intensified to make the candidate aware of, inter-alia,

- Department's policies and programmes,

- Dynamics within - be they political or administrative,

- Inter-departmental programmes/activities - thinking;

- A spirit, culture and practice of collaboration, teamwork and collegiality among all public servants.

The induction programme needs to be structured in a way that emphasizes the importance of policy and programme implementation in a department. If this culture is inculcated in the employees at the entry level, induction and training programmes can be a useful tool in ensuring the implementation of policies and programmes and may be seen as an intervention.

\section{Local Government turn-around Strategy}

In the 2011 State of the Nation Address, President J. Zuma, having admitted that there are frustrations that communities experience with governance at the local sphere said, "We have instituted a turnaround strategy for local government, focusing on, amongst others, the strengthening of basic administrative systems, financial management and customer care" (2011:14). The President further confirmed the building of a responsive, 
accountable, effective, and efficient local government. The local government turnaround strategy aimed at the following:

- Better planning and oversight over local service delivery - remove constraints on service delivery;

- Address constitutional and legislative weaknesses in municipal governance;

- Professionalization and administrative stabilization of local government undertake steps to strengthen professionalism of local government;

- Establish a single window of co-ordination for local government - establish a single point of entry for the support, monitoring and intervention in local government, national sphere must inform sub-national spheres when visiting municipalities;

- Deepen people-centred government through a refined model of ward committees - priorities of all three spheres of government must find expression in the work of ward committees and these committees must be coordinated at a municipal, district, provincial and national level;

- Reform the intergovernmental fiscal system - improve coordination of various grants to local government and address equity and compliance challenges (Local Government Turnaround Strategy 2009:29-39).

The introduction of the strategy manifests government's intention to improve the functioning of the local sphere of government. It is indeed a monitoring and intervention tool, which if practiced can facilitate the implementation of policies and programmes. It lays emphasis on professionalism, monitoring and intervention, planning and oversight which are all essential ingredients of monitoring and evaluation.

\section{Conclusion}

In this article, various tools to improve or better the implementation of government policies and programmes and thus ensure a better life for all have been suggested. It can also be stated that in order for the tools to yield the desired results there is a need 


\section{Potential Benefits of Monitoring \& Evaluation in the South African Local Govt Spheres}

for public officials to change their mindset and be transformed from bureaucracy (rule bound), to revocracy (getting things done immediately).

On the positive side, there are people of integrity in the municipalities (lots of them) who are concerned about the state of affairs in municipalities. These individuals need to be reassured that they are not alone, that there is a caring society that is permanently annoyed by the status quo and is ready to roll up its sleeves and do what it takes to achieve clean governance. That will require working with municipalities, faith-based organizations, the private sector and other structures of civil society. Building strong, capable municipalities can never be the domain of municipal officials and councillors alone. The public needs to be involved; civil society needs to claim its space to influence progress.

The era of appointing candidates, who lack skills and know-how, to positions of authority is over. Officials who are found guilty of corruption in municipalities should not be given a life-line of again being employed in any other municipality. Ward Committees, as a link between municipalities and communities, need to be more vigilant as they are key in monitoring and evaluation. The need to restructure the operations of the N.A.C.H, for it to be effective, cannot be over emphasized. The establishment of a Monitoring and Evaluation Commission may have positive spin-offs as a monitoring and evaluation tool. Government induction and training programmes need to focus more on the implementation of policies as this is important if the goals of ensuring a better life for all are to be achieved. Coupled with this contention is the need to have leaders of integrity leading in public institutions.

It can also be deduced that public officials are expected to be professional and ethical in the performance of functions because the dearth of these virtues will hamper any attempts by government to ensure a better life for all. These virtues are paramount if the monitoring and evaluation tools have to be effective. 


\section{List of References}

- $\quad$ A.J. Diale 2010 : Journal of Public Administration, Volume 45 number 1.1

- $\quad$ Anti-corruption Hotline (NACH) 2003, Sherewo Printers, Pretoria.

- Auditor General Report 2010/2011, Office of the Auditor General Pretoria.

- Capacity Development Action Briefs, United Nations Development Programme, 2007: Case evidence on ethics and values in civil service reforms

- Craythorne D. L 2003: Municipal Administration: The Handbook, $5^{\text {th }}$ edition, Juta and CO; Ltd Lansdowne.

- De Bruin, H and Dick, W 2006: Strategies for safe guarding public values in liberalized utility sectors, Public Administration, 84 (3)

- Fox. W. Schwella, E and Wissink, H 1991: Public Management, Juta \& Company Ltd, Kenwyn.

- Ijeoma. E, Nzewi, O and Sibanda M, 2013: South Africa's Public Administration for Community Service, Independent Service Delivery Monitoring Networks (ISDMN) South Africa.

- $\quad$ Kondlo, K and Maserumule 2010: The Zuma Administration Critical Challenges, HSRC Press, Cape Town.

- Promotion of Access to Information Act, 2000, Government Printer, Pretoria.

- Public Service Commission Report, 2010, Public Service Commission, Pretoria.

- Public Service Reputations 2001, Government Printers, Pretoria.

- $\quad$ R Thakhathi, Inaugural address, University of Fort Hare Bhisho, September 2013

- Shafriz, J.M. and Russel E.W. 2005: Introduction to Public Administration, $4^{\text {th }}$ edition, Pearson, New York

- State of the Nation Address, Office of the Presidency, Pretoria.

- The Constitution of the Republic of South Africa, 1996, Government Printer, Pretoria. 


\section{Potential Benefits of Monitoring \& Evaluation in the South African Local Govt Spheres}

- The Handbook for Municipal Councillors, South African Local Government Association, Pretoria.

- The Local Government Municipal Systems Amendment Act, 2011, Government Printer, Pretoria.

- The Local Government Turnaround Strategy, 2009, Department of co-operative Governance and Traditional Affairs, Republic of South Africa.

- $\quad$ The U.N. Corruption Convention, 2005.

- United Nations Department of Economic and Social Affairs Division for Public Economics and Public Administration 2000: Professionalism and Ethics in the Public Service, Issues and Practices in Selected Regions, United Nations, New York.

\section{AUTHOR'S CONTACT}

\section{MLE, T.R}

School of Public Administration

University of Fort Hare

South Africa

Email: Tmle@ufh.ac.za

\section{AFRICA'S PUBLIC SERVICE DELIVERY} AND PERFORMANCE REVIEW

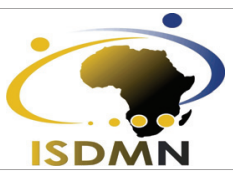

